\title{
Effect of forage grass (Pennisetum pedicellatum) and legume (Stylosanthes hamata) revegetation on recovery of soil fertility in a reclaimed hazardous waste dump
}

\author{
Sneha Kumari ${ }^{1}$, Jitendra Ahirwal ${ }^{1}$, and Subodh Kumar Maiti ${ }^{2}$ \\ ${ }^{1}$ Indian Institute of Technology (Indian School of Mines) Dhanbad \\ ${ }^{2}$ Indian Institute of Technology
}

July 20, 2020

\begin{abstract}
Dumping of hazardous waste causes land degradation, air, and water pollution, deteriorates landscape and aesthetics, which can be controlled by reclaiming with grass-legume seeding. The study aimed to examine the effect of grass-legume revegetation between 1- and 5-years in a restored waste dump (hazardous waste of an integrated steel plant) reclaimed with coir-matting, topsoil blanketing followed by grass (Pennisetum pedicellatum) and legume (Stylosanthes hamata) seeding. We hypothesized that the synergistic effect of the grass-legume mixture would lead to an increase in productivity and soil fertility. To assess the effects, changes in root and shoot biomass, mulch accumulation, nitrogen (N) mineralization, and its effect on soil fertility were measured. Our results showed between 1- to 5 -years legume and grass biomass increased by $44 \%$ and $37 \%$, respectively. An increase in mulch density and thickness along with revegetation age potentially increased the soil moisture by $7.5 \%$ and lowered soil temperature by $9^{\circ} \mathrm{C}$ at $10 \mathrm{~cm}$ depth. Cumulative $\mathrm{N}$-mineralization by legume was three-fold higher than the grass. Soil organic carbon (SOC), available N, total N, N-stock, and soil respiration was doubled after 5-years of revegetation. Dehydrogenase and urease activity increased by $44 \%$ and $56 \%$ respectively, indicating greater $\mathrm{C}$ and $\mathrm{N}$ accumulation at the dump surface. The study concluded that grass (P. pedicellatum) and legume (S. hamata) mixture can be used for reclamation of the waste dump that accelerates recovery of the fertility of disturbed topsoil by contributing mulch with increasing age of revegetation.
\end{abstract}

\begin{abstract}
Dumping of hazardous waste causes land degradation, air, and water pollution, deteriorates landscape and aesthetics, which can be controlled by reclaiming with grass-legume seeding. The study aimed to examine the effect of grass-legume revegetation between 1- and 5-years in a restored waste dump (hazardous waste of an integrated steel plant) reclaimed with coir-matting, topsoil blanketing followed by grass (Pennisetum pedicellatum ) and legume (Stylosanthes hamata) seeding. We hypothesized that the synergistic effect of the grass-legume mixture would lead to an increase in productivity and soil fertility. To assess the effects, changes in root and shoot biomass, mulch accumulation, nitrogen $(\mathrm{N})$ mineralization, and its effect on soil fertility were measured. Our results showed between 1- to 5 -years legume and grass biomass increased by $44 \%$ and $37 \%$, respectively. An increase in mulch density and thickness along with revegetation age potentially increased the soil moisture by $7.5 \%$ and lowered soil temperature by $9^{\circ} \mathrm{C}$ at $10 \mathrm{~cm}$ depth. Cumulative Nmineralization by legume was three-fold higher than the grass. Soil organic carbon (SOC), available N, total $\mathrm{N}, \mathrm{N}$-stock, and soil respiration was doubled after 5-years of revegetation. Dehydrogenase and urease activity increased by $44 \%$ and $56 \%$ respectively, indicating greater $\mathrm{C}$ and $\mathrm{N}$ accumulation at the dump surface. The study concluded that grass (P. pedicellatum ) and legume (S. hamata) mixture can be used for reclamation of the waste dump that accelerates recovery of the fertility of disturbed topsoil by contributing mulch with
\end{abstract}


increasing age of revegetation.

Keywords: Reclamation; topsoil; mulch; nitrogen; soil $\mathrm{CO}_{2}$ flux; waste dump

\section{INTRODUCTION}

Soils are being degraded worldwide due to industrial activities and the inevitable dumping of solid wastes. The solid waste generated from an integrated sponge iron plant consists of dolochar, slag, and fly ashes, dumped together causes deterioration of aesthetics, and acts as continuous sources of pollution. They caused severe air pollution problems during the summer, while in monsoon, the loose waste was easily carried away along with run-off to pollute the nearby water bodies. The waste is very homogenous, loose, and devoid of nutrients, hence stabilization of this type of waste poses a severe challenge. Additionally, the dumping of waste materials alters the surface soil horizon (native topsoil) at the disposal site. Therefore, proper handling and sustainable management of hazardous waste are essential to minimize land degradation and environmental pollution.

Ecological restoration is the only remedy that causes the degradation of solid wastes with time and regenerating the natural aesthetics of the land. The restoration method may involve the application of fertile topsoil, covering the exposed slope area with geotextile mat, different soil amendments, revegetation with grass-legume seed mixture, and selective plantation. Every step involved its associated primary benefit which aids in the process of restoration. Geotextile mats are beneficial for topsoil water retention and vegetation growth on abandoned wastelands (Shao et al., 2014). To develop quick vegetation cover, control erosion, and minimize pollution, seeding of grass-legume mixtures has now become a widely used technique to restore soil fertility of wastelands (Maiti, 2012; Shang et al., 2014). With time, grass and legume litter eventually dry and produces mulch which decomposes to form humus and regenerates the soil organic layer (Maiti \& Maiti 2015).

A variety of plant species has been used to stabilize dump surface but the selection of plant species that can provide an adequate vegetation cover has an added advantage. Grasses and legumes quickly aid in developing thick ground cover and decomposition of biomass residues contribute organic matter (Maiti, 2012; Maiti \& Maiti, 2015; Shang et al., 2014). For instance, proportional seeding of the grass-legume mixture showed improvement in the soil nutrients in degraded pasture soil of Cerrado, Brazil (Marques et al., 2016). Seeding of grass (Cynodon dactylon and Paspalum notatum, ) and legume (Medicago sativa, Indigofer tinctoria, Amorpha fruticose, and Lespedeza bicolor ) mixture attributed significant improvement in the initial vegetation cover of highway slopes along with recovery of soil physicochemical properties (Yang et al., 2016). Natural regeneration of exotic legume Leucaena leucocephala showed the potential to recover soil fertility compared to grasses predominant on mine waste dumps of varying ages in Brazil (Lima et al., 2018). The introduction of legume (M. sativa) on abandoned farmlands increased biomass cover as well as soil $\mathrm{N}$ concentrations during 1 to 11 years of revegetation (Yuan et al. 2016). Addition of legume $M$. sativa also increased aboveground net primary productivity along with soil carbon $(\mathrm{C})$, nitrogen $(\mathrm{N})$ and phosphate (P) storage in a sandy grassland amended with sediment (Wu et al., 2019). Grass species, such as Chrysopogon zizanioides, Pennisetum macrourum, Pennisetum polystachion, and Pennisetum purpureum were used to restore wastelands in Southwest Ethiopia (Talema et al., 2019). Under drought stress conditions, root length and root area of grasses are more than legumes at the 30-60 cm depth of soil (Wang et al., 2020). A greenhouse study reported that an increase in soil $\mathrm{N}$ concentrations and development of diverse microbial communities were observed when invasive legume (Lespedeza cuneate) introduced with native grass (Schizachyriu mscoparium) in a mixture (Fill, Pearson, Knight, \& Crandall, 2020).

Soil organic matter $(\mathrm{SOM})$ and available $\mathrm{N}$ instantly declines in topsoil due to land degradation which usually takes time to recover (Maiti \& Maiti, 2015). Plant-derived biomass residues in the form of mulch can accelerate the accretion of soil nutrients. The quantity and chemical composition ( $\mathrm{N}$ concentration and C:N ratio) of the organic mulch residues are variables which determines decomposition rate, predict the amount of potentially mineralizable N (PMN) and nutrients release affecting soil quality (Halde \& Entz, 2016; Ibrahim, Abaidoo, Fatondii, \& Opoku, 2018; Radicetti et al., 2017). Mulching thickness shows a direct positive effect 
on soil moisture content and reduces soil surface temperature (Kader, Senge, Majid, \& Ito, 2017; Pramanik et al., 2015; Wang et al., 2017). Indirectly, decomposition of litter/organic mulches by microbes also adds to the SOM that simultaneously augments the $\mathrm{C}$ and $\mathrm{N}$ pools and helps in carbon sequestration (Frouz, 2018; Guoju et al., 2020; Zhang et al., 2019). Organic mulching has been preferred for years because it is eco-friendly, saves labor cost and after decomposition, adds biomass nutrients to soils.

We investigated the effect of forage grass (Deenanath grass;Pennisetum pedicellatum Trin.) and legume (Caribbean stylo;Stylosanthes hamata (L.) Taub.) revegetation and gradual enrichment of mulch on soil fertility of the reclaimed waste dump. We hypothesized that the synergistic effect of grass-legume revegetation would lead to an increase in the restoration of productivity and soil fertility with time. The objectives of the present study were to (i) assess the changes in soil physicochemical and biological properties under grasslegume mixture at two developmental ages of revegetation (between 1- and 5-years), (ii) examine the effect of biomass residue (mulch) on soil fertility of the revegetated waste dump, and (iii) analyze the role of grass and legume biomass residue in $\mathrm{N}$-mineralization.

\section{MATERIALS AND METHODS}

\subsection{Study area}

The experimental plot was established on the solid waste dump of the Nalwa Steel and Power Limited (NSPL) located in the Raigarh district of Chhattisgarh, India (Figure 1). NSPL is an operating integrated steel plant that manufactures sponge iron by the direct reduction process. The aerial extent of the waste dump lies between $83^{\circ} 22^{\prime} 35^{\prime \prime} \mathrm{E}$ to $83^{\circ} 23^{\prime} 27^{\prime \prime} \mathrm{E}$ and $22^{\circ} 00^{\prime} 51^{\prime \prime} \mathrm{N}$ to $22^{\circ} 02^{\prime} 10^{\prime \prime} \mathrm{N}$ covering an area of approximately 7 hectares. The dump height ranged between $40-50 \mathrm{~m}$ with a slope of more than $60-70^{\circ}$ inclination. The area experience subtropical climate with temperature ranged between $8-49^{\circ} \mathrm{C}$ and the mean annual precipitation was $750 \mathrm{~mm}$. The waste materials were dumped externally at the outskirts of the steel plant surrounded by Shorea robustadominated forest.

The main stages involved in sustainable closure and subsequent reclamation of the waste dump were as follows (Figure 2): (a) leveling of the surface, compaction and maintaining slope of 1:3 for proper surface runoff, (b) re-grading of slopes and blanketed with coirmats followed by topsoil and seeded with grass-legumes seeds, (c) safety measures like stone pitching at the toe of the dump and construction of garland drain, (d) re-grading the surface before applying forest topsoil up to 0.6-1 $\mathrm{m}$ depth, (e) for stabilization of the slope and sidewalls coir mats of dimension $(1 \mathrm{~m} \times 30 \mathrm{~m})$ were used, (f) for the development of green cover in the initial stage, seed mixture of grass $(P$. pedicellatum $)$ and legume $(S$. hamata ) in a 1:1 ratio was sown. the view of stabilized dumps after 5 years, with the development of mulch covers in lean season (summer), is shown in Figure 3. In the berm of dumps, tillers of lemongrass (Cymbopogon citratus ) were planted. Tree species like Azadirachta indica, Leucaena leucocephala, Acacia nilotica, Pongamia pinnata were also planted on the edges to increase dump stability.

\subsection{Biomass sampling and analysis}

A total of 10 sampling points was randomly selected at the waste dump and an area of $1 \mathrm{~m}^{2}$ at each point was marked for vegetation sampling. We used the harvest method to estimate shoot and root biomass. Soil particles attached to roots were separated by soaking and washing with a fine jet of water with ultrasonicator. During soil sampling, rooting depth was measured (i.e., depth of root penetration). Shoot and root biomass was separated and oven-dried at $65^{\circ} \mathrm{C}$ for 48 hours to measure the weight of the dry biomass. Biomass samples were finely grounded and a sieved $(<1 \mathrm{~mm})$ to determine the total carbon $(\mathrm{C})$ and nitrogen $(\mathrm{N})$ using an elemental analyzer (Euro EA 3000 Eurovactor, Italy). Dry mulch accumulated on the surface layer was collected by using quadrate (size: $30 \mathrm{~cm} \times 30 \mathrm{~cm}$ ), from the same location where soil and vegetation samples were collected.

\subsection{Nitrogen mineralization}

Grass and legume residues (0.2 gm on a dry weight basis; $<1 \mathrm{~mm}$ size) mixed with topsoil (20 gm; $<2 \mathrm{~mm})$ were packed in a plastic container and incubated at $28^{0} \mathrm{C}$ for 14 weeks to measure N-mineralization. Soil 
moisture content was maintained at $50 \%$ of field capacity throughout the experiment. Soil samples without plant residue were also incubated as control. The incubated soil samples were extracted with $100 \mathrm{ml} 1 \mathrm{M} \mathrm{KCl}$ solution by shaking for $1 \mathrm{~h}$ in an orbital shaker and filtered through Whatman \#42 filter paper at an interval of $1,2,3,4,6,8,10,12$ and 14 weeks. The inorganic $\mathrm{N}$ concentration in the soil extract was analyzed by the steam distillation method (Keeney \& Nelson, 1983).

\subsection{Soil sampling and analysis}

Soil samples were collected by laying random quadrats of $10 \mathrm{~m} \times 10 \mathrm{~m}$ on the surface of the waste dump after 1 and 5-years of revegetation and natural forest (NF) as reference. Within each quadrat, composite soil samples were obtained by mixing five subsamples. A total of 110 composite soil samples were collected in a similar manner, 10 samples each at a consecutive depth of $0-10$ and $10-20 \mathrm{~cm}$ from the forest and both the revegetated dumps and 10 samples from 5-years old revegetated dumps under $0,3,6,9$ and $12 \mathrm{~cm}$ mulch thickness using a stainless-steel soil corer of $10 \mathrm{~cm}$ height and $8 \mathrm{~cm}$ internal diameter. The collected soil samples were air-dried at room temperature $\left(25-29^{\circ} \mathrm{C}\right)$ for a week and lightly crushed with a mortar and pestle. The coarse soil particles $(>2 \mathrm{~mm}$ size) were separated from the crushed soil using standard mesh size gravimetrically. Bulk density (BD) was determined by the soil core method (Blake \& Hartge, 1986). Soil $\mathrm{pH}$ was determined potentiometrically in soil: water $(1: 2.5, \mathrm{w} / \mathrm{v})$ by the multi-parameter probe (HI2020, Hanna Instruments India). Soil organic carbon (SOC) was estimated by using the rapid dichromate oxidation technique (Nelson \& Sommers, 1996). Soil organic matter (SOM) was determined as the weight differences after a loss on ignition (LOI) between $105^{\circ} \mathrm{C}$ and $375^{\circ} \mathrm{C}$. Soil microbial biomass carbon (MBC) and nitrogen (MBN) were measured by chloroform fumigation /0.5 $\mathrm{M} \mathrm{K}_{2} \mathrm{SO}_{4}$ extraction method (Vance et al., 1987; Brookes et al., 1985). Soil urease activity (UA) was measured by the colorimetric method and the released $\mathrm{NH}_{4}{ }^{+}$was quantified by UV-VIS Spectrophotometer (Guan, 1986). Dehydrogenase activity (DHA) in soil was estimated using 2, 3, 5-triphenyl tetrazolium chloride as a substrate (Casida, Klein, \& Santoro, 1964). Plant available $\mathrm{N}(\mathrm{Av}-\mathrm{N})$ and total $\mathrm{N}$ concentration were determined using a semiautomatic nitrogen estimation system (KJELODIST-EAS VA, Pelican Equipment, India) (Subbiah \&Asija, 1956). Available phosphorus (Av-P) was determined by the Bray's method (Bray \& Kurtz, 1945) and Cation exchange capacity (CEC) of the soil was determined by Na-saturation method (soil was saturated with $1 \mathrm{~N}$ sodium acetate solution, washed with ethanol and subsequently treated with $1 \mathrm{~N}$ ammonium acetate) and measured by a flame photometer (ESICO-1388, Microprocessor flame photometer, India) (Jackson, 1973). Soil organic carbon and total $\mathrm{N}$ stock was calculated by using respective elemental concentration in soils, specific soil depth and bulk density as follows:

SOC or N stock $\left(\mathrm{Mg} \mathrm{ha}^{-1}\right)=[$ SOC or $N$ conc $\times \mathrm{BD} \times T \times 100](1)$

Where SOC is soil organic carbon concentration (\%), $\mathrm{N}$ is total nitrogen concentration (\%), BD is bulk density $\left(\mathrm{Mg} \mathrm{m}^{-3}\right)$, $\mathrm{T}$ is soil thickness $(\mathrm{m})$.

\subsection{Soil $\mathrm{CO}_{2}$ flux measurement}

Rate of soil $\mathrm{CO}_{2}$ flux was measured at the revegetated dump surface during two developmental ages and natural Sal forest for a week (24 hours every 20 min interval for 90 seconds) by LICOR LI-8100 Infrared gas analyzer (LICOR Inc. Lincoln, NE, USA). Temperature probe (type E-thermocouple, p/n 8100-201; 6.4 $\mathrm{mm}$ diameter, $25 \mathrm{~cm}$ length) was inserted up to a depth of $10 \mathrm{~cm}$ to record soil temperature. Similarly, soil moisture was measured by a moisture probe (ECHO Model EC-5, p/n 8100-202; 5 cm length). The Probe output is given as $\mathrm{mV}(700-1300 \mathrm{mV})$, and volume of water content is expressed as $\mathrm{m}^{3} / \mathrm{m}^{3}$ by using the following regression equation as given in the LI-8100 instruction manual:

$\operatorname{VWC}\left(\frac{m^{3}}{m^{3}}\right)=-3.14 \times 107 x m V+1.16 \times 103 x m V-0.612(2)$

In the laboratory, the calibration curve was prepared between millivolts $(\mathrm{mV})$ and moisture content (percent, $\mathrm{w} / \mathrm{w}$ basis) ranging from 525 to $1190 \mathrm{mV}$ and corresponding moisture percentage ranging from $0.5 \%$ (dry soil) to $20.4 \%$ (wet soil) was calculated as follows: 
Moisture $(\%, w / w$ basis $)=0.03 \times \mathrm{mV}-14.41\left[\mathrm{R}^{2}=0.909\right](3)$

\subsection{Statistical analysis}

The significant differences between the mean under different land covers were tested using analysis of variance (ANOVA) and compared by Tukey post hoc test at $\alpha[?] \quad 0.05$ significance level. The statistical relationship between different parameters and factors influencing them was assessed using Pearson correlation analysis. Regression analysis was carried out to investigate the relationship between the dependent variable ( $\mathrm{N}$-mineralization) with independent variables ( $\mathrm{TN}$ and $\mathrm{C}: \mathrm{N}$ ratio). All statistical analyses in this study were performed using SPSS21.0

\section{RESULTS}

\subsection{Changes in plant biomass and N-mineralization potential}

Growth of $S$. hamata and $P$. pedicellatum showed significant changes in rooting depth, shoot and root biomass, and mulch stock between the developmental ages of revegetation. The results showed that legumes biomass (26.82 $\mathrm{Mg} \mathrm{ha}{ }^{-1}$ ) was higher than the grass biomass $\left(19.02 \mathrm{Mg} \mathrm{ha}^{-1}\right.$ ) after 5 years of revegetation (Table 1). Biomass accumulation with the age since revegetation and their subsequent conversion to dead biomass increase mulch density from 11.4 to $28.0 \mathrm{Mg} \mathrm{ha}^{-1}$ (Figure 4). Continuous increase in mulch density resulted in greater mulch accumulation on the dump surface that has a significant effect on soil temperature and moisture content. The biomass residues showed a greater amount of $\mathrm{C}$ in grasses while $\mathrm{N}$ concentration was higher in legumes (Table 2). Inorganic $\mathrm{N}$ concentration in legume residue ranged from $2.18-2.55 \mathrm{~g}$ $\mathrm{kg}^{-1}$ compared to $0.32-1.44 \mathrm{~g} \mathrm{~kg}^{-1}$ in the grass with shoot biomass contributing the highest concentration. The biomass residues used for incubation showed differences in C:N ratio for a shoot (12.4) and root (22.6) of $S$. hamata and shoot (20.3) and root (31.1) of P. pedicellatum . Changes in labile N pool from soil extract amended with biomass residues were greater by legume than grass with incubation time (Figure 5). The mineralization rate showed greater values $\left(25-27 \mathrm{mg} \mathrm{N} \mathrm{kg}^{-1} \mathrm{wk}^{-1}\right)$ during the first 3-weeks of incubation and declined to $15 \mathrm{mg} \mathrm{N} \mathrm{kg}{ }^{-1} \mathrm{wk}^{-1}$ toward the $14^{\text {th }}$ week by the legume. Similarly, shoot biomass of grass

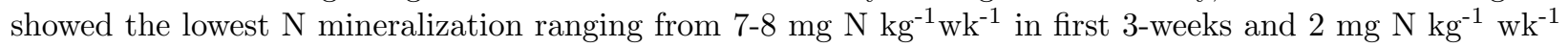
by the end of the incubation period. The cumulative $\mathrm{N}$ mineralization rate was greater by legume shoot biomass (166 mg N kg-1 soil) compared to grass (58 $\mathrm{mg} \mathrm{N} \mathrm{kg}^{1}$ soil). Linear regression analysis showed that the percentage of mineralized $\mathrm{N}$ was highly dependent on TN pool of decomposing biomass and negative curvilinear relationship with biomass C:N ratio in both shoot and root biomass of legume and grass (Figure $6)$.

\subsection{Changes in soil properties}

Changes in soil physicochemical and biological properties after 1 and 5-years of grass-legume revegetation were significantly different from natural forest soils (Table 3 ). The disturbed topsoil prior to grass-legume seeding had a pH (4.7), BD (1.26 g cm$\left.{ }^{-3}\right)$, Av-N (46.68 $\left.\mathrm{mg} \mathrm{kg}^{-1}\right)$, TN (389.60 $\left.\mathrm{mg} \mathrm{kg}^{-1}\right)$, SOM (0.81\%), SOC $(0.34 \%)$, Av-P $\left(0.74 \mathrm{mg} \mathrm{kg}^{-1}\right)$, UA $\left(1.26 \mu \mathrm{g} \mathrm{NH}{ }_{4}^{+} \mathrm{g}^{-1} \mathrm{~h}^{-1}\right)$, DHA $\left(1.57 \mu \mathrm{g}\right.$ TPF g $\left.\mathrm{g}^{-1} \mathrm{~h}^{-1}\right)$ and CEC $(5.23 \mathrm{cmol}$ $\left.\left(\mathrm{p}^{+}\right) \mathrm{kg}^{-1}\right)$. Changes in soil $\mathrm{pH}(5.8-5.6)$ with increasing age of revegetation were not significant $(\mathrm{p}>0.05)$. BD showed an increasing trend with soil depth and found highest in 1-year revegetated soil. A significant increase in the mulch density over the years resulted in favorable soil conditions which help increase the topsoil moisture content of the reclaimed waste dump from 3.8 to $11.8 \%$ compared to a natural forest (7.20\%) and decrease soil temperature $\left(26-23^{0} \mathrm{C}\right)$ at the top layer $(0-10 \mathrm{~cm})$ (Table 3; Figure 4). SOC concentrations doubled in 5 -years and significantly different $(\mathrm{p}<0.05)$ in both the soil depth. SOM concentration improved due to enrichment of grass-legume mulch which decomposed over the years but significantly lower compared to forest soil. Soil Av-N and Total-N concentrations were significantly greater after 5-years (132 and 1165 $\mathrm{mg} \mathrm{kg}{ }^{-1}$ ) compared to initial concentrations (54 and $579 \mathrm{mg} \mathrm{kg}^{-1}$ ) in the top layer. Decrease soil C:N ratio justifies greater accumulation of $\mathrm{N}$ over $\mathrm{C}$ due to an abundance of legume biomass residue. Both DHA and UA reduced with soil depth as maximum interaction of soil microbes was found to occur in the top surface $(0-10 \mathrm{~cm})$. Highest DHA was observed in forest soil $\left(10.14 \mu \mathrm{g} T P F \mathrm{~g}^{-1} \mathrm{~h}^{-1}\right)$ whereas DHA in reclaimed soil increased significantly $(\mathrm{p}<0.05)$ from 3.7 to $5.32 \mu \mathrm{g} \mathrm{TPF} \mathrm{g} \mathrm{g}^{-1} \mathrm{~h}^{-1}$ (Table 3$)$. Similarly, UA also showed a 
significant increase from $4.57-7.11 \mu \mathrm{g} \mathrm{NH} \mathrm{N}_{4}{ }^{-} \mathrm{g}^{-1} \mathrm{~h}^{-1}$ among the revegetated sites during 1 to 5 -years but nonsignificant when compared to forest soil. Soil $\mathrm{C}$ and $\mathrm{N}$ stocks increased significantly with revegetation age and decreased with the soil depth (Table 4). After 5-years of grass-legume revegetation SOC stock increase by $66 \%$ in the top layer. Soil $\mathrm{N}$ stock was also significantly higher $(\mathrm{p}<0.05)$ after 5 -years of revegetation $\left(1.47 \pm 0.21 \mathrm{Mg} \mathrm{ha}^{-1}\right)$ compared to forest $\mathrm{N}$ stock $\left(1.00 \pm 0.32 \mathrm{Mg} \mathrm{ha}^{-1}\right)$.

Additionally, an increase in mulch thickness $(0,3,6,9$, and $12 \mathrm{~cm})$ on the dump surface accelerated the soil microbial biomass $\mathrm{C}$ and $\mathrm{N}$ even in the early stages of revegetation promoting soil fertility. The level of improvement was highest with $12 \mathrm{~cm}$ mulch thickness for all the assessed soil parameters (Figure 7). The amount of potentially mineralizable biomass residues in the soil correlated positively with $\mathrm{N}$ pool, SOM, microbial, and enzyme activity (Table 5). Soil $\mathrm{CO}_{2}$ flux rates differ significantly under different land covers and showed peak values for NF (Figure 8). The mean soil $\mathrm{CO}_{2}$ flux was found in the order of natural forest $\left(3.17 \pm 0.55 \mu \mathrm{mol} \mathrm{m}{ }^{-2} \mathrm{~s}^{-1}\right)>5$-years $\left(1.21 \pm 0.15 \mu \mathrm{mol} \mathrm{m}{ }^{-2} \mathrm{~s}^{-1}\right)>1$-year $\left(1.01 \pm 0.62 \mu \mathrm{mol} \mathrm{m} \mathrm{m}^{-2} \mathrm{~s}^{-1}\right)$ reclaimed waste dump over the experimental periods of revegetation.

\section{DISCUSSION}

\subsection{Effect of grass-legume mixture on N-mineralization}

The growth of grass-legume mixture after 5 years of revegetation on the waste dump has substantially increased the biomass by $41 \%$ and mulch stock by $93 \%$ (Table 1). An increase in grass-legume mulch thickness up to $12 \mathrm{~cm}$ in 5-years showed a positive effect on moisture and temperature in the upper layer $(0-10 \mathrm{~cm})$ of soil. Due to an increase in mulch accumulation maximum soil temperature was dropped by $9^{\circ} \mathrm{C}$ which increased moisture content of the reclaimed dump surface by $7.5 \%$ compared to bare soil (Figure 2 ). These changes are attributable to thick surface mulch formed over the dump surface which creates a cooler soil environment, reduces evapotranspiration, and holds soil moisture by ameliorating the surface temperature. Our results are consistent with the findings of Wang, Liu, Wu, Li, \& Wang, (2017).

Microbial decomposition of biomass residue releases potential nutrients available to plant depends on the rate of mineralization which regulates the conversion of organic to inorganic N pool (Abdelhafez et al., 2018; Ansong Omari et al., 2018; Marzi, Shahbazi, kharazi, \& Rezaei, 2020). Inorganic N concentration in legume shoot and root biomass accounted for $0.91 \%$ and $0.42 \%$ respectively of the biomass total $\mathrm{N}$ pool whereas cumulative N-mineralization by legume residues were three-folds greater than the grass (Table 2; Figure 5). The study of $\mathrm{C}$ and $\mathrm{N}$ mineralization reported that net $\mathrm{N}$ mineralization was greater by legumes (33\%) than non-legumes (20\%) species and differs across shoot and root biomass of both the species (Li et al., 2020; Li et al. 2019). The increase in labile $\mathrm{N}$ pool in the reclaimed dump soil indicates the presence of mineralizable organic $\mathrm{N}$ contributed by legume and grass biomass in the mixture after one to five years of revegetation.

After 5-years of revegetation, increase in soil moisture and the enrichment of mulch stock constituting highquality $\mathrm{N}$ rich legume biomass with low $\mathrm{C}: \mathrm{N}$ ratio enhances the $\mathrm{N}$-mineralization process (Figure 6; Figure 7) and makes it desirable for the functioning of microbial populations (Jilkova, Strakova, \& Frouz, 2020; Lei \& McDonald, 2019; Li et al., 2019). Legume biomass with low C:N ratio can be readily decomposed by soil microbes leaving excess $\mathrm{N}$ in soil that can be used by associated plant species whereas, higher C:N ratio of grass biomass contributes to soil $\mathrm{C}$ but in long term, the accumulation of SOC can be controlled by $\mathrm{N}$ concentration. These difference in the chemical characteristics of the biomass residues of grass-legume mixture incorporated in soil shifts the nutrient cycling via mineralization which stimulated the soil microbial activities (Amorim et al.,2020; Bhandari, West, \& Acosta-Martinez, 2020; Prommer et al., 2020) and enzymatic activities (Joniec, 2018; Sekaran et al., 2020; Tian et al., 2017). Therefore, understanding the N mineralization patterns of grass and legume biomass returned to the soil during revegetation is important for the management of soil $\mathrm{N}$ dynamics in nutrient cycling.

\subsection{Effect of grass-legume mixture on SOM and enzymes activity}

Soil fertility in terms of SOM, C and N concentration readily declines in topsoil during initial use at the waste dumpsite, which can be recovered through revegetation and subsequent nutrient cycling via decomposition 
and mineralization (Campos, Etchevers, Oleschko, \& Hidalgo, 2014; de Oliveira et al., 2015; Semenov et al., 2019). Analysis of variance (ANOVA) showed that the growth of grass-legume mixture on dump surface bought significant changes in both above and below-ground soil systems (Table 3). Enrichment of grasslegume mulch over 5-years of revegetation increased the SOC and SOM concentration by $94 \%$ and $35 \%$ respectively in 0-10 cm depth. However, when compared with forest soil, both SOC and SOM concentration was still $23 \%$ and $111 \%$ lower in reclaimed soil. Similarly, SOC and N stock in the blanketed soil also showed increment by $66 \%$ and $122 \%$, respectively, after 5 -years compared to initial concentration (Table 4 ). These differences are mainly attributed to the presence of rapidly decomposing legume residue, impedes the recovery of SOM, and potentially available forms of $\mathrm{C}$ and $\mathrm{N}$ pool governed by soil microbes and plant rooting depth will absorb a large amount of the nutrient, leading to increased microbial activity. Previous studies have also reported that the incorporation of legume biomass helps in the recovery of soil C (Guan et al., 2016; Wu, Liu, Tian, \& Shi, 2017) and N stock in the early stage of biological reclamation (Ahirwal, Maiti, \& Reddy, 2017a; Elgersma \& Soegaard, 2016).

The changes in root and shoot biomass and mulch accumulation in mixture modifies the composition of mulch residue added to the soil, which resulted from an increase in $\mathrm{N}$ mineralization, promotes $\mathrm{C}$ and $\mathrm{N}$ recovery link to increase soil microbial biomass $\mathrm{C}$ and $\mathrm{N}$ (Figure 7). At the same time, enzymes related to soil $\mathrm{C}$ and $\mathrm{N}$ decomposition processes i.e. dehydrogenase and urease enzyme activity demonstrate 56 and $44 \%$ increase, respectively after 5 years of revegetation compared to $1^{\text {st }}$ year which probably reflected the general build-up of the microbial biomass. These results show the positive correlation and linkage between nutrient parameters, microbial and enzyme activities in a high decomposition driven soil environment (Table 5) that are in agreements with the similar trends explained in other studies (Hou et al., 2018; Luo et al., 2018; Zuber \& Villamil, 2016). During land use change, plantation of legume (M. sativa ) significantly improved the soil $\mathrm{N}$ concentration and urease enzyme activity after 3-years of the plantation (Yu, Lin, Liu, \& Wang, 2020). Our finding illustrates the fact that reclaimed soils under grass-legume revegetation have higher $\mathrm{N}$ mineralization potential and beneficial for the growth of soil microbial biomass that is related to enzyme activities that play a crucial role in effective recovery of soil nutrients during revegetation.

\subsection{Effect of grass-legume mixture on soil $\mathrm{CO}_{2} \mathrm{flux}$}

The decomposition of grass-legume mulch over 5-years of revegetation, influence microbial respiration and increased $\mathrm{CO}_{2}$ flux of the reclaimed waste dump by $19 \%$. Soil $\mathrm{CO}_{2}$ flux attributed by natural forest was 1.5 times greater than the 5-years old reclaimed waste dump (Figure 8). Variation in the rate of soil $\mathrm{CO}_{2}$ fluxes can be due to the difference in soil temperature, litter/biomass input, and plant root growth (Frouz, 2017). Higher $\mathrm{N}$ concentration of the legume shoot and root residues showed an efficacious effect on soil $\mathrm{N}$ pool whereas higher root $\mathrm{C}$ in grass residue built soil $\mathrm{C}$ pool and increases $\mathrm{CO}_{2}$ efflux and their addition as mulch available for microbes increases the soil microbial respiration throughout the stages of decomposition. An increase in labile $\mathrm{C}$ pool would increase soil respiration as the grass biomass residues reduce $\mathrm{N}$ leaching i. e. positive priming effect (Frouz, Novotna, Cermakova, \& Pivokonsky, 2020; Wu et al., 2020). Root biomassderived $\mathrm{C}$ compared to shoot biomass $\mathrm{C}$ have been reported to contribute greater and relatively stable soil C pools (Ghafoor, Poeplau, \& Katterer, 2017). Apparently, these differences gradually declined during microbial decomposition because soil C:N ratio decreased after 1-5 years of revegetation (Table 3). Liu et al. (2020) reported the benefits of legume biomass (Caragana korshinskii) on the Loess Plateau of China showed greater potential to sequester soil C. Similarly, 7-years of perennial legume M. sativa, Lespedeza davurica, and Astragalus adsurgens growth increased the soil $\mathrm{C}$ sequestration of arable land by 79,68 and $74 \%$ (Guan et al., 2016). The rate of $\mathrm{CO}_{2}$ flux, unlike other soil parameters, respond more quickly under varying soil temperature and the quality of organic matter to assess soil fertility (Ahirwal, Maiti, \& Singh, 2017b; Munoz-Rojas, Erickson, Dixon, \& Merritt, 2016) indicating whether the soil conditions are favorable for decomposition process in long term revegetation.

\section{Conclusions}

Dense grass-legume mulch cover formed over 5-years of revegetation created a buffer zone between soil and atmospheric temperature and helps retain soil moisture content. Legume with low biomass C:N ratio 
favor rapid $\mathrm{N}$ mineralization conversely, high C: $\mathrm{N}$ ratio of grass biomass reduces $\mathrm{N}$ leaching by enhancing microbial $\mathrm{N}$ uptake and synergistically contributing balanced mineralization of $\mathrm{N}$ in the soil. Soil fertility in terms of SOM, SOC, N, microbial biomass, and enzyme activity was significantly increased after 5-years of grass-legume revegetation that are close to the natural forest soils. Growth of grass-legume mixture also enhanced the microbial activity, $\mathrm{SOC}$ and $\mathrm{N}$ stocks, and doubling the rate of $\mathrm{CO}_{2}$ flux in 5-years. Field-scale reclamation of waste dumps requires a massive amount of mulch and often impractical to import. Therefore, we recommend grass-legume revegetation, as they provide sufficient shoot and root biomass and subsequent mulch stock over time. In conclusion, this study shows that legume (S. hamata $)$ is compatible with grass $(P$. pedicellatum ) species affecting above and below ground soil systems during revegetation, increase nutrient concentrations, and accelerates recovery of soil fertility.

\section{Acknowledgement}

The first author would like to thank the Indian Institute of Technology (Indian School of Mines), Dhanbad for providing research fellowship and other research facilities during this study. The authors appreciate the help of Mr. M.L. Sahu, Head EHS of Nalwa Steel and Power Limited (NSPL), Raigarh for assisting us in their dumpsites for sampling and experimentation work.

Conflict of interest: The authors do not have a conflict of interest in any form.

\section{REFERENCES}

Abdelhafez, A. A., Abbas, M. H., Attia, T. M., El Bably, W., \& Mahrous, S. E. (2018). Mineralization of organic carbon and nitrogen in semi-arid soils under organic and inorganic fertilization. Environmental Technology \& Innovation, 9 , 243-253. https://doi.org/10.1016/j.eti.2017.12.011

Ahirwal, J., Maiti, S.K., \&Reddy, M.S. (2017a). Development of carbon, nitrogen and phosphate stocks of reclaimed coal mine soil within 8 years after forestation with Prosopis juliflora (Sw.) Dc. Catena, 156 , 42-50. https://doi.org/10.1016/j.catena.2017.03.019

Ahirwal, J., Maiti, S. K., \& Singh, A. K. (2017b). Changes in ecosystem carbon pool and soil CO2 flux following post-mine reclamation in dry tropical environment, India. Science of the Total Environment,583 , 153-162. https://doi.org/10.1016/j.scitotenv.2017.01.043

Amorim, S. P., Nascimento, D., Boechat, C. L., Duarte, L. D. S. L., Rocha, C. B., \& Carlos, F. S. (2020). Grasses and legumes as cover crops affect microbial attributes in oxisol in the cerrado (savannah environment) in the northeast region 1. Revista Caatinga ,33 (1), 31-42. https://doi.org/10.1590/1983-21252020v33n104rc

Ansong Omari, R., Bellingrath-Kimura, D. S., Fujii, Y., Sarkodee-Addo, E., Appiah Sarpong, K., \& Oikawa, Y. (2018). Nitrogen mineralization and microbial biomass dynamics in different tropical soils amended with contrasting organic resources. Soil Systems , 2 (4), 63. https://doi.org/10.3390/soilsystems2040063

Bhandari, K. B., West, C. P., \& Acosta-Martinez, V. (2020). Assessing the role of inter seeding alfalfa into grass on improving pasture soil health in semi-arid Texas High Plains. Applied Soil Ecology ,147, 103399. https://doi.org/10.1016/j.apsoil.2019.103399

Blake, G. R., \& Hartge, K. H. (1986). Bulk density. Methods of soil analysis: Part 1 Physical and mineralogical methods , 5 , 363-375. https://doi.org/10.2136/sssabookser5.1.2ed.c13.

Bray, R. H., \& Kurtz, L. T. (1945). Determination of total, organic, and available forms of phosphorus in soils. Soil Science ,59 (1), 39-46.

Brookes, P. C., Landman, A., Pruden, G., \& Jenkinson, D. S. (1985). Chloroform fumigation and the release of soil nitrogen: a rapid direct extraction method to measure microbial biomass nitrogen in soil.Soil Biology and Biochemistry , 17 (6), 837-842. https://doi.org/10.1016/0038-0717(85)90144-0

Campos, A. C., Etchevers, J. B., Oleschko, K. L., \& Hidalgo, C. M. (2014). Soil microbial biomass and nitrogen mineralization rates along an altitudinal gradient on the Cofre de Perote Volcano (Mexico): the 
importance of landscape position and land use. Land Degradation $\&$ Development , 25 (6), 581-593. https://doi.org/10.1002/ldr.2185

Casida Jr, L. E., Klein, D. A., \& Santoro, T. (1964). Soil dehydrogenase activity. Soil Science , 98 (6), 371-376.

de Oliveira, S. P., de Lacerda, N. B., Blum, S. C., Escobar, M. E. O., \& de Oliveira, T. S. (2015). Organic carbon and nitrogen stocks in soils of northeastern Brazil converted to irrigated agriculture.Land Degradation \& Development , 26 (1), 9-21. https://doi.org/10.1002/ldr.2264

Elgersma, A., \&Soegaard, K. (2016). Effects of species diversity on seasonal variation in herbage yield and nutritive value of seven binary grass-legume mixtures and pure grass under cutting. European Journal of Agronomy , 78 , 73-83. https://doi.org/10.1016/j.eja.2016.04.011

Fill, J. M., Pearson, E., Knight, T. M., \& Crandall, R. M. (2019). An invasive legume increases perennial grass biomass: An indirect pathway for plant community change. PloS one, 14 (1), e0211295. https://doi.org/10.1371/journal.pone.0211295.

Frouz, J. (2017). Effects of soil development time and litter quality on soil carbon sequestration: Assessing soil carbon saturation with a field transplant experiment along a post-mining chronosequence. Land Degradation \&6 Development , 28 (2), 664-672. https://doi.org/10.1002/ldr.2580

Frouz, J. (2018). Effects of soil macro-and mesofauna on litter decomposition and soil organic matter stabilization. Geoderma ,332, 161-172. https://doi.org/10.1016/j.geoderma.2017.08.039

Frouz, J., Novotna, K., Cermakova, L., \& Pivokonsky, M. (2020). Soil fauna reduce soil respiration by supporting N leaching from litter.Applied Soil Ecology , 153 , 103585. https://doi.org/10.1016/j.apsoil.2020.103585

Ghafoor A., Poeplau, C., Katterer, T. (2017) Fate of straw- and root derived carbon in a Swedish agricultural soil. Biology and Fertility of Soils, 53 , 257-267. https://doi.org/10.1007/s00374-016-1168-7

Guan, S.Y. (1986). Soil enzyme and its research approaches; China Agriculture Press: Beijing, China.

Guan, X. K., Turner, N. C., Song, L., Gu, Y. J., Wang, T. C., \& Li, F. M. (2016). Soil carbon sequestration by three perennial legume pasture $\mathrm{s}$ is greater in deeper soil layers than in the surface soil.Biogeosciences, 13 (2), 527. https:// doi:10.5194/bg-13-527-2016

Guoju, X., Yanbin, H., Qiang, Z., Jing, W., \& Ming, L. (2020). Impact of cultivation on soil organic carbon and carbon sequestration potential in semiarid regions of China. Soil Use and Management ,36 (1), 83-92. https://doi.org/10.1111/sum.12540

Halde, C., \& Entz, M. H. (2016). Plant species and mulch application rate affected decomposition of cover crop mulches used in organic rotational no-till systems. Canadian Journal of Plant Science ,96 (1), 59-71. https://doi.org/10.1139/cjps-2015-0095

Hou, H., Wang, C., Ding, Z., Zhang, S., Yang, Y., Ma, J., \& Li, J. (2018). Variation in the soil microbial community of reclaimed land over different reclamation periods. Sustainability , 10 (7), 2286. https://doi.org/10.3390/su10072286

Ibrahim, A., Abaidoo, R. C., Fatondji, D., \& Opoku, A. (2015). Integrated use of fertilizer micro-dosing and Acacia tumidamulching increases millet yield and water use efficiency in Sahelian semi-arid environment. Nutrient Cycling in Agroecosystems ,103 (3), 375-388. https://doi.org/10.1007/s10705-015-9752-z

Jackson, M. L. (1958). Soil chemical analysis prentice Hall. Inc., Englewood Cliffs, NJ , 498 , 183-204.

Jilkova, V., Strakova, P., \&Frouz, J. (2020). Foliage C: N ratio, stage of organic matter decomposition and interaction with soil affect microbial respiration and its response to $\mathrm{C}$ and $\mathrm{N}$ addition more than $\mathrm{C}$ : $\mathrm{N}$ changes during decomposition. Applied Soil Ecology , 152 , 103568. https://doi.org/10.1016/j.apsoil.2020.103568 
Joniec, J. (2018). Enzymatic activity as an indicator of regeneration processes in degraded soil reclaimed with various types of waste.International Journal of Environmental Science and Technology ,15 (10), 2241-2252. https://doi.org/10.1007/s13762-017-1602-x

Kader, M. A., Senge, M., Mojid, M. A., \& Ito, K. (2017). Recent advances in mulching materials and methods for modifying soil environment. Soil and Tillage Research , 168 , 155-166. https://doi.org/10.1016/j.still.2017.01.001

Keeney, D. R., \& Nelson, D. W. (1983). Nitrogen-Inorganic forms. In AL Page et al.(ed.) Methods of soil analysis. Part 2. 2nd ed. Agron. Monogr. 9. ASA and SSSA, Madison, WI. p. 643-698. https://doi.org/10.2134/agronmonogr9.2.2ed.c33.

Lei, L., \& McDonald, L. M. (2019). Soil moisture and temperature effects on nitrogen mineralization in a high tunnel farming system.Communications in Soil Science and Plant Analysis , 50 (17), 2140-2150. https://doi.org/10.1080/00103624.2019.1654503

Li, F., Sorensen, P., Li, X., \& Olesen, J. E. (2020). Carbon and nitrogen mineralization differ between incorporated shoots and roots of legume versus non-legume based cover crops. Plant and Soil ,446 (1), 243-257. https://doi.org/10.1007/s11104-019-04358-6

Li, Z., Tian, D., Wang, B., Wang, J., Wang, S., Chen, H. Y., \& Niu, S. (2019). Microbes drive global soil nitrogen mineralization and availability. Global Change Biology , 25 (3), 1078-1088. https://doi.org/10.1111/gcb.14557

Lima, M. T., Ribeiro, A. I., Dias, H. C. T., Rosa, A. G., Pires, G. T., \& Tonello, K. C. (2018). The dynamics of the substrate recovery of waste dumps in calcary mining under natural regeneration. Cerne ,24 (1), 18-26. https://doi.org/10.1590/01047760201824012476

Liu, W., Yu, Z., Zhu, Q., Zhou, X., \& Peng, C. (2020). Assessment of biomass utilization potential of Caragana korshinskii and its effect on carbon sequestration on the Northern Shaanxi Loess Plateau, China. Land Degradation 83 Development , 31 (1), 53-64. https://doi.org/10.1002/ldr.3425

Luo, G., Rensing, C., Chen, H., Liu, M., Wang, M., Guo, S., \& Shen, Q. (2018). Deciphering the associations between soil microbial diversity and ecosystem multifunctionality driven by long-term fertilization management. Functional Ecology ,32 (4), 1103-1116. https://doi.org/10.1111/1365-2435.13039

Maiti, S. K. (2012). Ecorestoration of the coalmine degraded lands . Springer Science \& Business Media.

Maiti, S. K., \& Maiti, D. (2015). Ecological restoration of waste dumps by topsoil blanketing, coir-matting and seeding with grass-legume mixture. Ecological Engineering, 77, 74-84. https://doi.org/10.1016/j.ecoleng.2015.01.003

Marques, A. R., Vianna, C. R., Monteiro, M. L., Pires, B. O. S., de Carvalho Urashima, D., \& Pontes, P. P. (2016). Utilizing coir geotextile with grass and legume on soil of Cerrado, Brazil: An alternative strategy in improving the input of nutrients in degraded pasture soil? Applied Soil Ecology , 107 , 290-297. https://doi.org/10.1016/j.apsoil.2016.06.002

Marzi, M., Shahbazi, K., Kharazi, N., \& Rezaei, M. (2020). The influence of organic amendment source on carbon and nitrogen mineralization in different soils. Journal of Soil Science and Plant Nutrition, 20 (1), 177-191. https://doi.org/10.1007/s42729-019-00116-w

Munoz-Rojas, M., Erickson, T. E., Dixon, K. W., \& Merritt, D. J. (2016). Soil quality indicators to assess functionality of restored soils in degraded semiarid ecosystems. Restoration Ecology ,24 , 43-52. https://doi.org/10.1111/rec.12368

Nelson, D. W., \& Sommers, L. E. (1996). Total carbon, organic carbon, and organic matter. Methods of soil analysis: Part 3 Chemical methods , 5 , 961-1010. 
Pramanik, P., Bandyopadhyay, K. K., Bhaduri, D., Bhattacharyya, R., \& Aggarwal, P. (2015). Effect of mulch on soil thermal regimes-A review. International Journal of Agriculture, Environment and Biotechnology , 8 (3), 645-658. https://doi.org/10.5958/2230-732X.2015.00072.8

Prommer, J., Walker, T. W., Wanek, W., Braun, J., Zezula, D., Hu, Y., \& Richter, A. (2020). Increased microbial growth, biomass, and turnover drive soil organic carbon accumulation at higher plant diversity. Global Change Biology , 26 (2), 669-681. https://doi.org/10.1111/gcb.14777

Radicetti, E., Campiglia, E., Marucci, A., \& Mancinelli, R. (2017) How winter cover crops and tillage intensities affect nitrogen availability in eggplant. Nutrient Cycling in Agroecosystems, 108 , 177-194. https://doi.org/10.1007/s10705-017-9849-7

Sekaran, U., Loya, J. R., Abagandura, G. O., Subramanian, S., Owens, V., \& Kumar, S. (2020). Intercropping of kura clover (Trifoliumambiguum M. Bieb) with prairie cordgrass (Spartina pectinata link.) enhanced soil biochemical activities and microbial community structure. Applied Soil Ecology ,147, 103427. https://doi.org/10.1016/j.apsoil.2019.103427

Semenov, V. M., Pautova, N. B., Lebedeva, T. N., Khromychkina, D. P., Semenova, N. A., \& de Gerenyu, V. L. (2019). Plant residues decomposition and formation of active organic matter in the soil of the incubation experiments. Eurasian Soil Science, 52 (10), 1183-1194. https://doi.org/10.1134/S1064229319100119

Shang, Z. H., Cao, J. J., Guo, R. Y., Long, R. J., \& Deng, B. (2014). The response of soil organic carbon and nitrogen 10 years after returning cultivated alpine steppe to grassland by abandonment or reseeding. Catena , 119 , 28-35. https://doi.org/10.1016/j.catena.2014.03.006

Shao, Q., Gu, W., Dai, Q. Y., Makoto, S., \& Liu, Y. (2014). Effectiveness of geotextile mulches for slope restoration in semi-arid northern China. Catena , 116 , 1-9. https://doi.org/10.1016/j.catena.2013.12.006

Subbiah, B. V., \& Asija, G. L. (1956). A rapid procedure for assessment of available nitrogen in soils. Current Science, 25, 259-260.

Talema, A., Poesen, J., Muys, B., Padro, R., Dibaba, H., \& Diels, J. (2019). Survival and growth analysis of multipurpose trees, shrubs, and grasses used to rehabilitate badlands in the subhumid tropics. Land degradation \&3 Development , 30 (4), 470-480. https://doi.org/10.1002/ldr.3239

Tian, J., Wei, K., Condron, L. M., Chen, Z., Xu, Z., Feng, J., \& Chen, L. (2017). Effects of elevated nitrogen and precipitation on soil organic nitrogen fractions and nitrogen-mineralizing enzymes in semi-arid steppe and abandoned cropland. Plant and Soil ,417 (1-2), 217-229. https://doi.org/10.1007/s11104-017-3253-6

Vance, E. D., Brookes, P. C., \& Jenkinson, D. S. (1987). An extraction method for measuring soil microbial biomass C. Soil biology and Biochemistry , 19 (6), 703-707.

Wang, J., Liu, H., Wu, X., Li, C., \& Wang, X. (2017). Effects of different types of mulches and legumes for the restoration of urban abandoned land in semi-arid northern China. Ecological Engineering , 102 , 55-63. https://doi.org/10.1016/j.ecoleng.2017.02.001

Wang, G., Liu, S., Fang, Y., \& Shangguan, Z. (2020). Adaptive changes in root morphological traits of Gramineae and Leguminosae seedlings in the ecological restoration of the semiarid region of northwest China.Land Degradation $\&$ Development, 1-13. https://doi.org/10.1002/ldr.3616

Wu, G. L., Liu, Y., Tian, F. P., \& Shi, Z. H. (2017). Legumes functional group promotes soil organic carbon and nitrogen storage by increasing plant diversity. Land Degradation $\& 3$ Development ,28 (4), 1336-1344. https://doi.org/10.1002/ldr.2570

Wu, H., Lu, L., Zhang, Y., Xu, C., Yang, H., Zhou, W., .. \& \& Han, X. (2019). Sediment addition and legume cultivation result in sustainable, long-term increases in ecosystem functions of sandy grasslands.Land Degradation \& Development , 30 (14), 1667-1676. https://doi.org/10.1002/ldr.3348 
Wu, X., Xu, H., Tuo, D., Wang, C., Fu, B., Lv, Y., \& Liu, G. (2020). Land use change and stand age regulate soil respiration by influencing soil substrate supply and microbial community. Geoderma ,359 , 113991. https://doi.org/10.1016/j.geoderma.2019.113991

Yang, Y., Yang, J., Zhao, T., Huang, X., \& Zhao, P. (2016). Ecological restoration of highway slope by covering with straw-mat and seeding with grass-legume mixture. Ecological Engineering , 90 , 68-76. https://doi.org/10.1016/j.ecoleng.2016.01.052

Yu, T., Lin, F., Liu, X., \& Wang, X. (2020). Recovery Role in Soil Structural, Carbon and Nitrogen Properties of the Conversion of Vegetable Land to Alfalfa Land in Northwest China. Journal of Soil Science and Plant Nutrition, 1-12. https://doi.org/10.1007/s42729-020-00218-w

Yuan, Z. Q., Yu, K. L., Epstein, H., Fang, C., Li, J. T., Liu, Q. Q., \& Li, F. M. (2016). Effects of legume species introduction on vegetation and soil nutrient development on abandoned croplands in a semi-arid environment on the Loess Plateau, China. Science of the Total Environment, 541 , 692-700. https://doi.org/10.1016/j.scitotenv.2015.09.108

Zhang, R., Huang, Q., Yan, T., Yang, J., Zheng, Y., Li, H., \& Li, M. (2019). Effects of intercropping mulch on the content and composition of soil dissolved organic matter in apple orchard on the loess plateau.Journal of Environmental Management, 250 , 109531. https://doi.org/10.1016/j.jenvman.2019.109531

Zuber, S. M., \&Villamil, M. B. (2016). Meta-analysis approach to assess effect of tillage on microbial biomass and enzyme activities. Soil Biology and Biochemistry , 97, 176-187. https://doi.org/10.1016/j.soilbio.2016.03.011

\section{FIGURE CAPTION}

FIGURE 1 (a) Location map of the study area Chhattisgarh, India (b) satellite view of the reclaimed waste dump of Nalwa Steel and Power Limited (c) Early-revegetated waste dump surface showing growth of grass-legume mixture in the slope (after 1 year).

FIGURE 2 Sequence of reclamation of waste dump (a) regrading of dump slope, (b) blanketing the dump surface with topsoil, (c) slope is blanketed with coir mat and soil with grass-legumes seeded, and (d) the growth of grass-legume mixture on the dump slope.

FIGURE 3 Reclaimed dumps after 5-years (a) growth of grass-legumes at the dump surface, (b) growth of grass-legume at the dump slope, (c) accumulation of grass-legume mulch at the dump surface, and (d) accumulation of mulches on the waste dump slope.

FIGURE 4 Variation in mulch thickness, mulch density, soil moisture, soil temperature and air temperature at the reclaimed wasted dump with developmental ages of grass-legume revegetation.

FIGURE 5 Net $\mathrm{N}$ mineralization $\left(\mathrm{mg} \mathrm{kg}^{-1} \mathrm{week}^{-1}\right)$ in topsoil with shoot and root biomass residues of (a) legume (Stylosanthes hamata), and (b) grass (Pennisteum pedicellatum ).

FIGURE 6 Correlations between (a) mineralized N (\%) and total nitrogen (TN\%) concentration in legume biomass, (b) mineralized $\mathrm{N}(\%)$ and total nitrogen (TN\%) concentration in grass biomass, (c) mineralized $\mathrm{N}$ (\%) and C:N ratio of legume biomass and, (d) mineralized $\mathrm{N}(\%)$ and C:N ratio of grass biomass.

FIGURE 7 Effect of grass-legume mulch thickness on reclaimed soil properties (a) moisture, (b) soil organic matter (SOM), (c) microbial biomass carbon (MBC), (d) microbial biomass nitrogen (MBN), and (e) potentially mineralizable nitrogen (PMN) relative to bare soil (without mulch) with developmental ages of revegetation.

FIGURE 8 Averaged soil $\mathrm{CO}_{2}$ flux measured at reclaimed waste dump after 1 and 5-years of revegetation with grass-legume mixture and natural forest (NF).

\section{Hosted file}


Tables (16-07-2020).docx available at https://authorea.com/users/343769/articles/470365effect-of-forage-grass-pennisetum-pedicellatum-and-legume-stylosanthes-hamatarevegetation-on-recovery-of-soil-fertility-in-a-reclaimed-hazardous-waste-dump
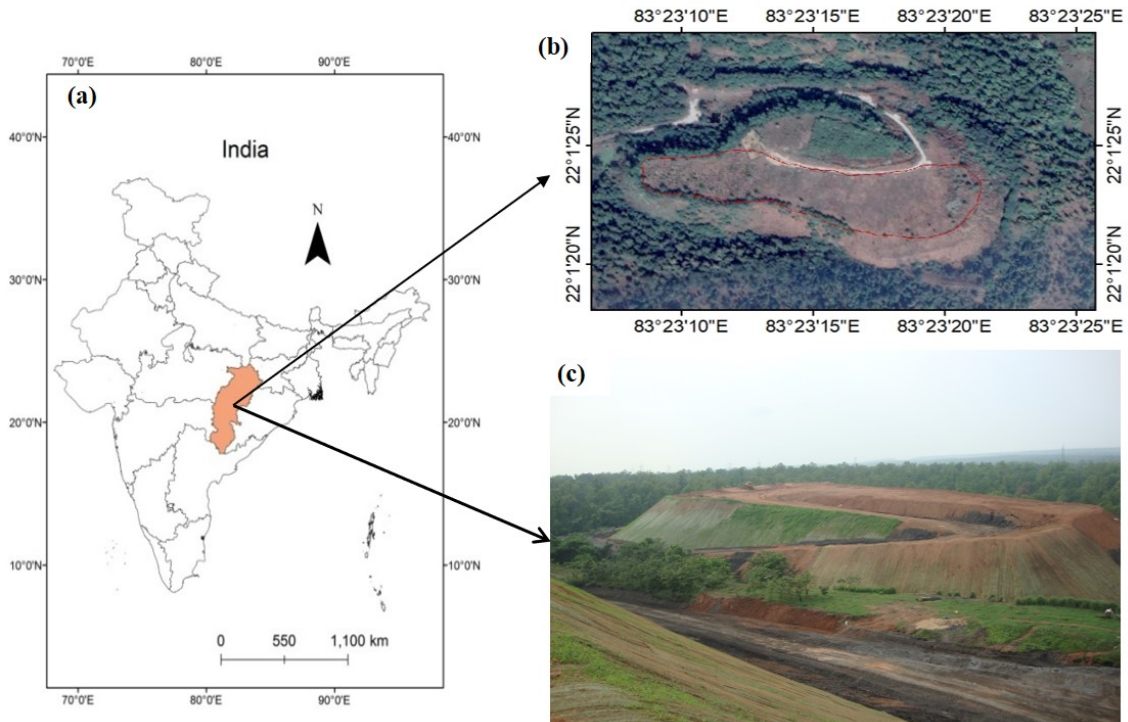

(c)
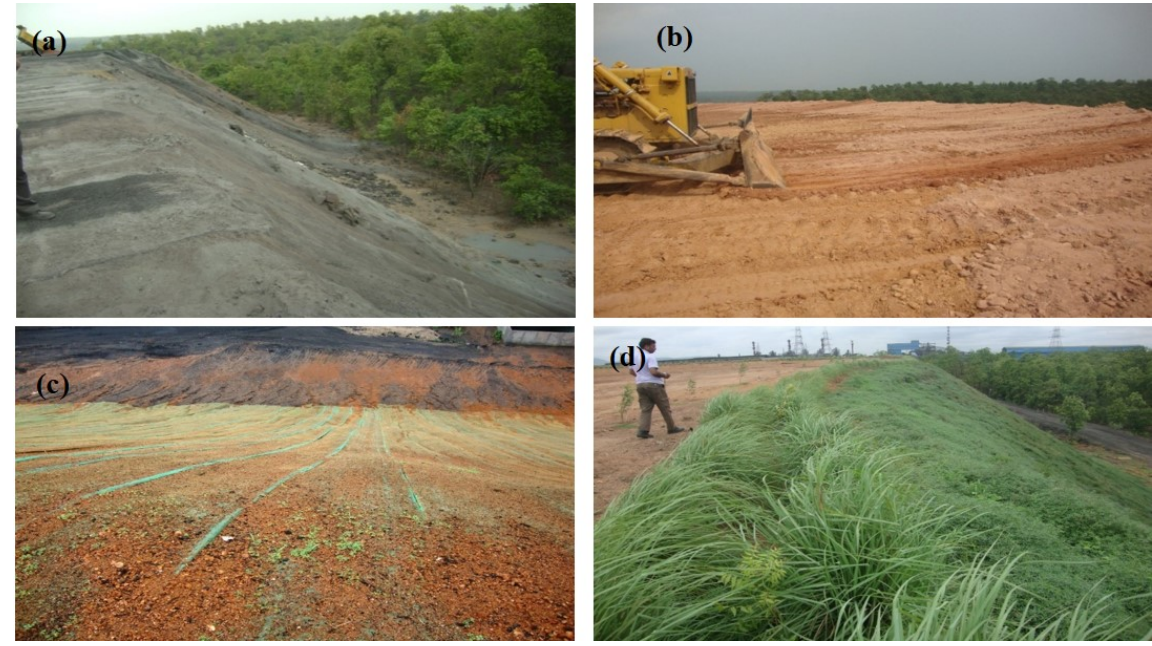


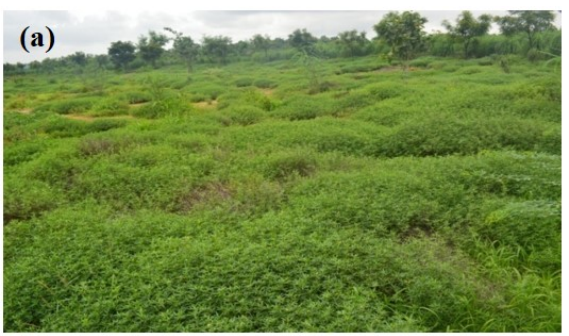

(b)
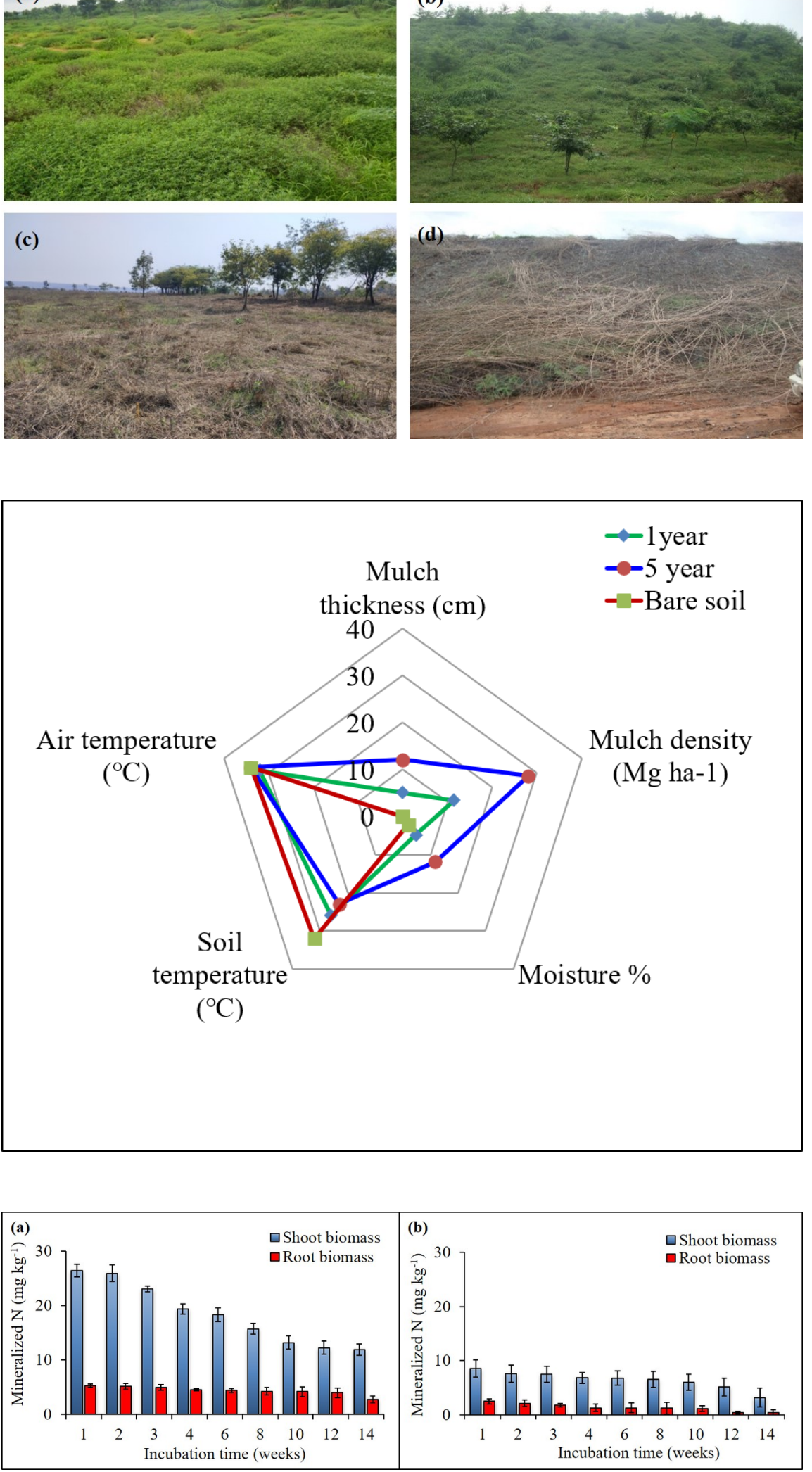

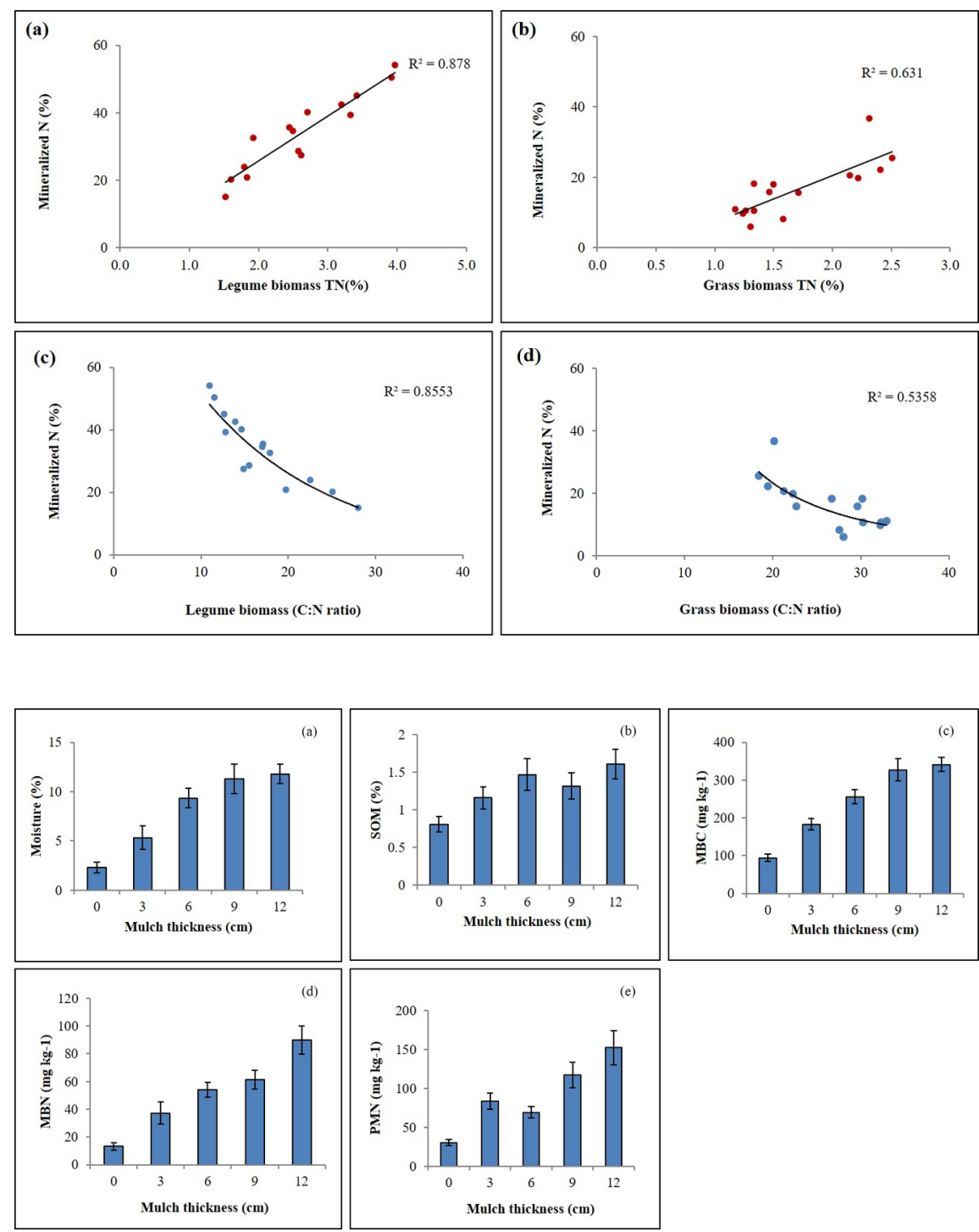


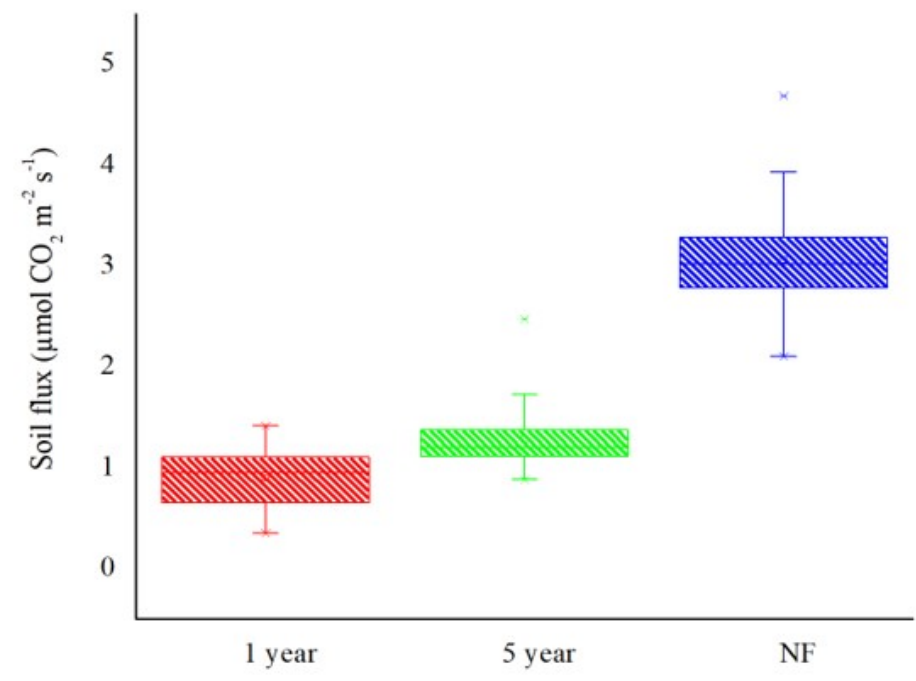

